УДК 94 (477.73) «-05/-00» : [323.3-058.12:177.72]

DOI: https://doi.org/10.33782/eminak2021.1(33).503

\title{
ОСОБЛИВОСТІ БЛАГОДІЙНИЦТВА В ОЛЬВІЙСЬКОМУ ПОЛІСІ (VI-I ст. до н.е.)
}

\author{
Оксана Ручинська \\ Харківський національний університет імені В.Н. Каразіна (Харків, Україна) \\ e-mail: o.a.ruchynska@karazin.ua \\ ORCID: https://orcid.org/0000-0002-6776-1598
}

у статті надається аналіз благодійницької діяльності в Ольвійському полісі, притаманної як громадянам Ольвії, так і іноземиям. На основі епіграфічних джерел висвітлюються характерні риси благодійництва з моменту заснування поліса та до кінця елліністичного періоду. Стверджується, що благодійницька практика Ольвійської еліти була близька до евергетизму, в елліністичний період вона відображала соціальну гідність й оціночні орієнтири громадянського колективу.

Ключові слова: благодійництво, евергетизм, Ольвійський поліс, еліта, громадянський колектив

Практика благодійництва була активно залучена до суспільного життя грецьких полісів Середземномор'я та Причорномор'я. Це явище, головним чином, притаманне періодам найскладніших економічних і військово-політичних ситуацій. Благодійники полісів здійснювали свої «добрі справи» довільно у зв'язку з наявними потребами (у формі літургій), або регулярно, під час виконання державних обов'язків в якості магістратів 1 .

Проблема благодійництва в Ольвійському полісі, незважаючи на накопичений матеріал (перш за все епіграфічні джерела), до теперішнього моменту все ще повноцінно не вивчена. В існуючих з цього питання дослідженнях, переважно розглядаються окремі благодійники або вузький хронологічний період, що не дозволяє виявити специфіку благодійницької діяльності у межах Ольвійського суспільства в історичному ракурсі². Метою нашого дослідження є спроба певної систематизації наявних даних щодо благодійництва в Ольвії з моменту заснування полісу в VI ст. до н.е. до гетської навали у середині I ст. до н.е.

Витоки благодійницької діяльності в Ольвії пов'язані з появою у полісі релігійних аристократичних союзів (фіасів) - мольпів і борейків. Свідчення щодо

\footnotetext{
1 у сучасних дослідженнях під благодійництвом у полісах Середземномор'я та Причорномор'я мається на увазі практика надання заможними та знатними особами різноманітних благодіянь

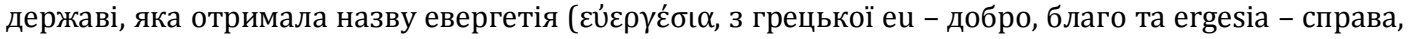
праця). Див.: Gygax M.D. Benefaction and rewards in the ancient Greek City: the origins of euergetism. Cambridge, New York: Cambridge University Press, 2016. P. 79-90, 199-243.

2 Відносно окремих благодійників див.: Русяева А.С. Абаб, сын Каллисфена - политический деятель Ольвии Понтийской // Античный мир и археология. Саратов, 2002. Вып. 11. С. 182-186; Иванчик А.И. Стефан, сын Александра из Смирны: Ольвия и ее эвергет второй половины II в. до н.э. // Нумизматика и эпиграфика. 2011. Т. 18. С. 15-29. Більш детально про діяльність благодійників у Північному Причорномор'ї епохи еллінізму див.: Angel S. Euergetai in the Greek Cities in the Black Sea during the Hellenistic Age // MarNero. 1999/2000. Vol. 4. P. 89-115; Avram A. La défense des cités en mer Noire à la basse époque hellénistique // Citoyenneté et participation à la basse époque hellénistique: actes de la table ronde des 22 et 23 mai 2004, Paris / Ed. P. Fröhlich, Ch. Müller. Genève, 2005. P. 163-184.
} 
впровадження в Ольвії у третій чверті VI ст. до н.е. культу Аполлона Дельфінія дозволили А.С. Русяєвій зробити висновок відносно виникнення у той самий час колегії мольпів ${ }^{3}$. Фіас мольпів був найдавнішим аристократичним чоловічим союзом, пов'язаним з виконанням сакральних обов'язків у культі Аполлона (Аполлона Дельфінія) у Мілеті. Суть обов'язків полягала в організації та проведенні членами колегії найважливіших релігійних церемоній ${ }^{4}$ Члени союзу мольпів в Ольвії мали не тільки аристократичне походження, але й володіли значними коштами. Вони займалися організацією священних обрядів, і щорічно, при зміні свого айсимнета, приносили у дар покровителю поліса Аполлону Дельфінію статуї, мармурові присвятні плити, колони ${ }^{5}$.

Ольвійські графіті свідчать про існування у полісі культу Аполлона Борея та пов'язаного з ним релігійного союзу з VI ст. до н.е. ${ }^{6}$ Фіас борейків так само був перенесений в Ольвію з Мілета, де в архаїчний період існувала відповідна філа7. Аналіз ольвійського графіті III ст. до н.е. з іменами членів фіасу борейків, надав можливість А.С. Русяєвій припустити елітарну природу цього релігійного союзу та констатувати, що тривалий період його діяльність була пов'язана з організацією релігійного життя Ольвійського поліса ${ }^{8}$. Для порівняння зазначимо напис І ст. до н.е. - I ст. н.е. з Істрії, який свідчить що у даному полісі велика кількість благодійників входила саме до філи бореїв 9 .

Час виникнення та діяльність фіасів мольпів і борейків дозволяє припустити,

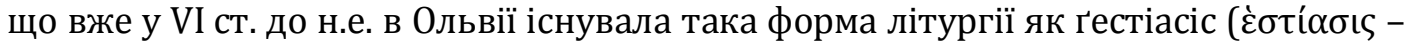
організація релігійних свят і громадських частувань). Підкреслимо, що під терміном «літургія» ( $\lambda \varepsilon ı \tau o u \rho \gamma i ́ \alpha)$, який згадується в Ольвійських написах, слід розуміти виконання окремих обов'язків у зв'язку з певною необхідністю10.

Починаючи з III-II ст. до н.е. організацією релігійних свят і громадських частувань займалися жерці храму Аполлона Дельфінія, більшість яких були евергетами (благодійниками) поліса ${ }^{11}$. Сприятливим фактором у даному випадку було існування в Ольвії заможних жрецьких родів, де обов'язки жерця передавалися у спадок: рід Евресибіадів, рід Діонісія, сина Діонісія та з II ст. до н.е. - жрецька сім'я, до якої входили Евбіот, син Аристона та Тімо, дочка Гіпсікреонта12. Однак

\footnotetext{
3 Русяева А.С. Религия и культы античной Ольвии. Киев: Наук. думка, 1992. С. 194.

${ }^{4}$ Ehrhardt N. Milet und seine Kolonien. Frankfurt am Main, Bern, New York: Lang, 1983. S. 143, 157.

${ }^{5}$ Карышковский П.О. Ольвийские мольпы // Северное Причерноморье: материалы по археологии. Киев,1984. С. $42-43$.

6 Русяева А.С. Милет-Дидимы-Борисфен-Ольвия. Проблемы колонизации Нижнего Побужья // Вестник древней истории. 1986. № 2. С. 59-60; для порівняння див.: Русяева А.С. Религия и культы античной Ольвии. Киев: Наук. думка, 1992. С. 196.

7 Ehrhardt N. Milet und seine Kolonien... S. 98.

8 Русяева А.С. Религия и культы античной Ольвии... С. 197, 427.

9 Inscripţiile din Scythia Minor greceşti şi latine / Ed. by D.M. Pippidi. București, 1983. Vol. I. Histria și împrejurimile, № 191. Про філу бореїв в полісах Західного Причорномор’я див.: Pippidi D.M. Scythica Minora: recherches les colonies grecques du littoral roumain de la mer Noire. București; Amsterdam: Acad. RSR, Hakkert, 1975. P. 193-196.

10 Латышев В.В. Исследования об истории и государственном строе Ольвии. Санкт-Петербург, 1887. C. 286.

11 Inscriptiones antiquae orae septentrionalis Ponti Euxini Graecae et Latinae / Ed. by V.V. Latyschev. Petropolis, 1916. Vol. 1. Ed. 2. № 201 (надалі IOSPE)

12 Детально про існуваня в Ольвії таких жрецьких родів див.: Виноградов Ю.Г. Политическая история Ольвийского полиса VII-I вв. до н.э.: Историко-эпиграфическое исследование. Москва: Наука, 1989. С. 220; Ольвия. Античное государство в Северном Причерноморье / Ред. С.Д. Крыжицкого, А.С. Русяевой, В.В. Крапивиной и др. Киев: Изд-во ИА НАНУ,1999. С. 429; Николаев Н.И. Просопография Ольвии Понтийской V в. до н.э. - I в. н.э. Киев: Изд-во О. Филюк, 2014. С. 22.
} 
традиція виконання літургї гестіасіс членами релігійних союзів Ольвії була продовжена й у період еллінізму. Наприклад, напис IV-III ст. до н.е. засвідчує ольвійський фіас, до складу якого входив філагафос (організатор культових трапез), який, згідно з текстом напису, активно виконував літургії через філотімію $\left(\varphi \iota \lambda о \tau \mu i^{\prime} \alpha\right)^{13}$. У даному випадку термін «філотімія» (благочестя) має велике значення, він призначався для того, щоб продемонструвати «добровільність» даної літургії та стимулювати благодійницьку діяльність інших громадян. Аналогічні спроби стимулювання літургічної діяльності громадян були характерним явищем у багатьох грецьких полісах елліністичного періоду 14.

Аналіз проксенічних і почесних декретів дозволяє говорити про те, що в Ольвійському полісі популярним був такий вид надзвичайної літургії як епідосіс

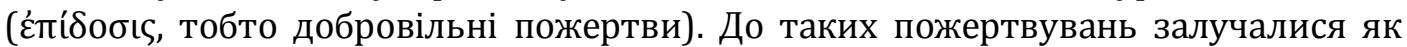
заможні іноземці, так і ольвіополіти. Слід підкреслити, що офіційних текстів, 3 подякою від громадянського колективу на адресу своїх благодійників, на ранніх етапах історії поліса ми не спостерігаємо. Перші заохочувальні дари особистостям, які займалися благодійницькою діяльністю в Ольвійському полісі, пов'язані з наданням проксеній іноземцям (ксенам). Положення благодійника (евергета) надавало іноземцям особливого статусу в Ольвійському полісі. Вже V ст. до н.е. датується декілька проксенічних декретів, пов'язаних з фінансовою допомогою Ольвії з боку іноземців, наприклад, від мешканців Синопи та Гераклеї Понтійської15. У цілому на догетський період історії Ольвії припадає 27 проксеній, а на період перших століть н.е. - лише близько 1116.

Слід зазначити, що невідомо за що саме вшановували іноземних благодійників до III ст. до н.е. Спочатку декрети не містили згадок конкретних заслуг ксенів перед полісом, і формулювання їхніх прав були типовими (проксенія, політія, ателія, вільний вхід і вихід 3 гавані у мирний і воєнний час) ${ }^{17}$. У почеснопроксенічному декреті III ст. до н.е. вже повідомляється, що Гелланік з Родосу вшановується за велику суму грошей, яку він надав для проведення громадських жертвоприношень в Ольвії18. Почесний декрет ольвіополітів останньої третини III ст. до н.е. на честь херсонесіта Аполлонія та його синів також повідомляє про значну фінансову допомогу, яку іноземці надали полісу19. Варто зауважити, що в якості подяки «добрим мужам» за благодіяння, Рада і народ Ольвії ухвалили:

\footnotetext{
13 IOSPE, № 201 - напис фіаса за припущенням А.О. Білецького, див.: Белецкий А.А. Греческая надпись на базе статуи из Ольвии // Вестник древней истории. 1955. № 2. С. 180-191; Надписи Ольвии (1917-1965) / Ред. Т.Н. Книпович, Е.И. Леви. Ленинград: Наука, 1968. № 71.

14 Gygax M.D. Benefaction and rewards in the ancient Greek City. P. 221.

15 Надписи Ольвии, № 1-2. Для порівняння див.: Брашинский И.Б. Древнейшая Ольвийская проксения // Советская археология. 1963. № 3. С. 191-196.

16 IOSPE, № 20-30; Надписи Ольвии, № 1-29. А.І. Іванчик виділяє загалом близько 40 проксеній, див.: Иванчик А.И. Стефан, сын Александра из Смирны: Ольвия и ее эвергет второй половины II в. до н.э. // Нумизматика и эпиграфика. 2011. Т. 18. С. 20. Дослідження інституту проксенії в інших регіонах Причорномор'я див.: Cojocaru V. Instituţia proxeniei în spaţiul pontic. Cluj-Napoca, 2016. P. 66-91.

17 Надписи Ольвии, № 20-23.

18 IOSPE, № 30.

${ }^{19}$ Напис складається з фрагментів, див.: Надписи Ольвии, № 28-29, 123; IOSPE, № 240. Детальну інтерпретацію текста див.: Виноградов Ю.Г., Русяева А.С. Культ Аполлона и календарь в Ольвии // Исследования по античной археологи Северного Причерноморья. Киев, 1980. С. 54; Яйленко В.П. Ольвийский декрет в честь сыновей херсонесита Аполлония // Вспомагательные исторические дисциплины. Ленинград, 1989. С. 252-268.
} 
увінчати їх золотим вінком, оголосити про увінчання на Діонісіях у театрі, запросити у перші ряди поміж інших благодійників під час вистав, пригостити (дослівно «запросити на частування») в храмі Аполлона і там же встановити почесну стелу й портретні рельєфи цим видатним іноземцям з Херсонесу20.

Особливої уваги заслуговує почесно-проксенічний декрет другої половини II ст. до н.е. - першої половини I ст. н.е. на честь Стефана, сина Олександра зі Смірни 21 . Даний декрет надає інформацію про пожертви коштів ксена на потреби поліса. Серед привілеїв, які отримав Стефан зі Смірни за свої благодіяння, поряд 3 публічним вихвалянням, проксенією, політією, вільним входом і виходом із гавані, йому були надані енктесіс (право придбання землі та нерухомості) та ісотелія (зрівняння в правах з громадянами у питаннях виплати мит). А.І. Іванчик акцентує увагу на тому, що енктесіс особливо наголошується в декреті, оскільки надавався в умовах економічної кризи, у той же час ісотелія була введена замість ателії, яка застосовувалася у попередніх декретах і була пов'язана із звільненням від сплати податків (що було свого роду благодійністю з боку держави) ${ }^{22}$. Крім того, серед почестей, що були надані Стефану, синові Олександра та його спадкоємцям, передбачався доступ до Ради і Народу відразу після рішення священних питань 23 .

Відзначимо, що в період облоги Ольвії у 311 р. до н.е. Зопіріоном, полководцем Олександра Македонського, в умовах військової загрози багатьом іноземцям були надані громадянські права та привілеї (Macrob. Saturn. 1, 2, 33)24. Надалі, у період економічної кризи III-II ст. до н.е., ці привілеї були значно обмежені. Заміна ателії ісотелією була покликана обмежити надання фіскальних привілеїв іноземцям з боку Ольвійського поліса. Однак взаємини з іноземними евергетами, що надавали послуги державі, як і раніше базувалися на ритуалізованій дружбі, яка була пов'язана з наданням в обмін на благодіяння певних привілеїв 25 . Період VIII ст. до н.е. був часом надання найбільшої кількості проксеній в Ольвії. Починаючи з III-II ст. до н.е., традицію прославлення іноземних благодійників за їх допомогу переймає на себе храм Аполлона Дельфінія, який підтримує звичай влаштування громадських трапез за участю іноземців. У цей період, як зазначає В. Кожокару, в Понтійському регіоні проксенії практично не відрізняються від

\footnotetext{
20 Яйленко В.П. Ольвийский декрет в честь сыновей херсонесита Аполлония. С. 252-253.

21 Надписи Ольвии, № 27. Доповнення див.: Виноградов Ю.Г. Митридат Евпатор и Ольвия // Древнее Причерноморье. Одесса, 1998. С. 42-45; Иванчик А.И. Стефан, сын Александра из Смирны. С. 15. Інша інтерпретація декрету див.: Яйленко В.П. Слово и дело: о публикации Ольвийского декрета в честь смирнейца Стефана // Античный мир и археология. Саратов, 2015. Вып. 17. С. $195-208$.

22 Иванчик А.И. Стефан, сын Александра из Смирны. С. 20; порівн.: Никитюк Е.В. Институт проксении в межполисных отношениях в классической Греции // Античное общество: власть и общество в античности. Санкт-Петербург, 2001. Вып. 4. С. 54-58.

${ }^{23}$ Кожокару В., Лицу А. Проксенические декреты как инструмент взаимоотношений с чужеземцами в понтийских греческих обществах и на острове Кос: предварительные итоги сравнительного исследования // Северное и Западное Причерноморье в античную епоху и средневековье. Симферополь, 2009. С. 195.

24 Див.: Жебелев С.А. Северное Причерноморье: Исследования и статьи по истории античной эпохи. Москва-Ленинград: Изд-во АН СССР, 1953. С. 47; Виноградов Ю.Г. Политическая история Ольвийского полиса VII-I вв. до н.э.: Историко-эпиграфическое исследование. Москва: Наука, 1989. С. $150-151$.

25 Про особливості «рітуалізованої дружби» між громадянами полісів та іноземцями див.:Herman G. Ritualized Friendship and the Greek City. Cambridge: Cambridge University Press, 2002. P. 130-142.
} 
почесних написів, а характер взаємин між громадянами й іноземними благодійниками, як ритуалізованої дружби, посилюється 26.

Поступово проксенії перетворюються у спробу вираження дипломатичної ввічливості та вшанування іноземців за їх благодіяння, швидше за уявні, ніж реальні, і стають формальними ${ }^{27}$.

Місцеві благодійники, починаючи з IV ст. до н.е., вшановувалися за надання матеріальних послуг місту та займалися його благоустроєм. Зауважимо, що в даний період, у зв'язку з утвердженням в Ольвії сталої демократії, з'являється традиція проголошення декретів на честь громадян, що особливо відзначились. Саме на період IV-II ст. до н.е. припадає найбільша кількість евергетів ольвійського поліса. Слід сказати, що поширення цього звичаю не було винятково Ольвійською традицією, це було загальногрецьке явище, яке торкнулося і Північного Причорномор' ${ }^{28}$.

Почесний декрет на честь Каллініка, сина Евксена свідчить, що у 330-320 pр. до н.е., цей видатний громадянин надав численні послуги місту, збільшив доходи поліса, налагодив карбування мідної монети, провів касацію боргів і втихомирив демос $^{29}$. За доброчинність його було відзначено почесним декретом, в якому зазначалося, що благодіяння були вчинені ним заради філотімії. Крім того, він був нагороджений вінком, великою грошовою винагородою у 1000 золотих, а також бронзовою, ймовірно, кінною статуєю ${ }^{30}$. Увінчання Каллініка слід було проголосити на Діонісіях у театрі31. Така форма винагороди вважалася дуже почесною у грецьких містах і надавалася особам, що особливо проявили себе у наданні послуг державі. В Афінах проголошення заслуг таких осіб зазвичай відбувалося в театрі під час Великих Діонісій ${ }^{32}$. Приклади увінчання видатних особистостей у театрі під час Діонісій відомі й у Причорномор'ї, наприклад, в Херсонесі ${ }^{33}$ та Месембрії ${ }^{34}$. У самій Ольвії проголошення в театрі на Діонісіях, ймовірно, відбувалося неодноразово, оскільки про це згадується і в декреті на честь синів херсонесіта Аполлонія 35.

Першою половиною III ст. до н.е. датований присвятний напис на постаменті статуї, згідно з текстом якого, громадяни Ольвії вшановували свого евергета

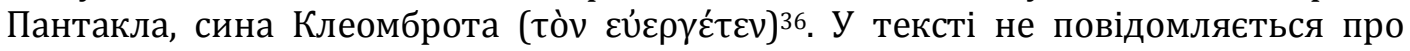

\footnotetext{
26 Кожокару В., Лицу А. Проксенические декреты как инструмент взаимоотношений с чужеземцами в понтийских греческих обществах и на острове Кос... С. 200-201.

27 Поглад на еволюцію проксенії та її взаємозв'язок з благодійництвом див.: Herman G. Op. cit. P. 129.

28 Gygax M.D. Op. cit. P. 230.

29 IOSPE, № 25, 31. Найбільш повно декрет досліджено Ю.Г. Віноградовим та П.О. Каришковським, див.: Виноградов Ю.Г., Карышковский П.О. Каллиник, сын Евксена // Вестник древней истории. 1982. № 4. С. 26-46; Виноградов Ю.Г. Политическая история Ольвийского полиса VII-I вв. до н.э. С. 153-164. 3 датуванням та інтерпретацією напису згодна А.С. Русяєва, див: Русяева А.С. Протоген Ольвийский // Археологія. 1993. № 2. С. 14-24.

30 Трейстер М.Ю. Материалы к корпусу постаментов бронзовых статуй Северного Причерноморья // Херсонесский сборник. 1999. Вып. 10. С. 122, № 3 (6).

31 IOSPE, № 25.

32 Див.: Goldhill S.D. The Great Dionysia and Civic Ideology // Journal of Hellenic Studies. 1987. Vol. 107. P. 58.

33 IOSPE, № 344.

34 Inscriptiones graecae in Bulgaria repertae / Ed by G. Mihailov. Serdicae, 1970. Vol. 1. Ed. 2. № 307.

35 Надписи Ольвии, № 28, 29, 123; IOSPE, № 240. Див.: Яйленко В.П. Ольвийский декрет в честь сыновей херсонесита Аполлония. С. 252-253.

36 IOSPE, № 188. Датування напису див.: Виноградов Ю.Г. Политическая история Ольвийского полиса VII-I вв. до н.э. С. 172.
} 
конкретні дії ольвійського благодійника, але за свої видатні заслуги перед Ольвією він був вшанований бронзовою статуєю37. У двох декретах згадується син Пантакла Клеомброт, який на власні кошти збудував башту, присвятивши їі Гераклу та народу Ольвії, а також відбудував частину муру 38 . Таким чином, можна констатувати, що традиція евергетії в окремих сім'ях Ольвії передавалася з покоління у покоління, і це свідчить про певну аристократизацію політичного життя поліса у цей час.

Найвидатнішим Ольвійским евергетом у III ст. до н.е. був Протоген, син Геросонта, який в умовах війн, неврожаїв та економічної кризи викупив закладені священні дари, забезпечив хлібом і вином громадян, організовував посольства, у тому числі, брав участь у посольстві до царя Сайтафарна. Протоген займався благоустроєм міста, добудував оборонні стіни, полагодив громадські кораблі, що возили будівельний камінь, полагодив житницю, в умовах навали варварів заспокоїв демос розумними порадами, пробачив борги народу, перед вступом на посаду в колегію Дев'яти дав 1500 золотих на рахунок майбутніх прибутків ${ }^{39}$. Зазначимо, що зазвичай надання коштів місту до вступу на посаду було характерним явищем у демократичних полісах класичного періоду. Натомість, благодійник Протоген зробив це у III ст. до н.е. в умовах складної економічної ситуації в Ольвії. Присвятний напис Аполлону Дельфінію від імені його онука Евмена свідчить, що Протоген і члени його родини, всупереч небезпеці, не залишали місто й надалі та продовжували здійснювати благодіяння 40.

Декрет на честь Протогена вказує на те, що він виконував свої діяння, орієнтуючись на честь та обов'язок перед громадянським суспільством, говорячи, що

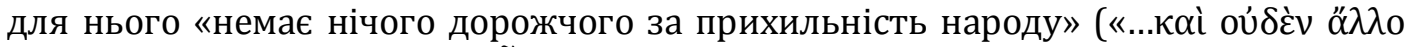

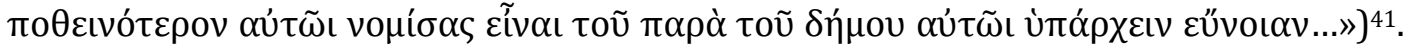
Зосередимо увагу на тому, що подібний пасаж не випадковий, у багатьох почесних декретах елліністичного періоду відзначається ставлення особи, яку вшановують, до суспільства (

Декрет першої половини II ст. до н.е. на честь Нікерата, сина Папія, свідчить про те, що всі діяння цього громадянина були спрямовані на благо вітчизни ${ }^{42}$. Доблесний громадянин Нікерат загинув, коли захищав громадян Ольвії у Гілеї, де вони проводили ігри ( $\alpha \gamma \omega \dot{\omega})$ на честь Ахілла, за що був посмертно відзначений почесним декретом. Він не тільки врятував громадян, але й гарантував безпеку місту, відбивши напад ворога, усунув суперечку між Ольвією та Херсонесом, надавав розумні поради громадянам і виконував постанови 43 . Нікерата, єдиного 3

\footnotetext{
37 Трейстер М.Ю. Материалы к корпусу постаментов бронзовых статуй Северного Причерноморья... С. 136, № 10 (14).

38 IOSPE, № 179, 180.

39 IOSPE, № 32, строки 29-64.

40 Русяева А.С. Религия и культы античной Ольвии... С. 58-77; Русяева А.С. Протоген Ольвийский... С. 14-24; Русяєва А.С., Крапівіна В.В. До історії Ольвії IV-І ст. до н.е. // Археологія. 1992. № 4. С. $17-$ 34.

41 IOSPE, № 32, строки 89-90.

42 IOSPE, № 33. В.В. Латишев датує декрет першими десятиліттями I ст. до н.е., див.: Латышев В.В. Исследования об истории и государственном строе Ольвии... С. 139. Ю.Г. Віноградов, який спирається на палеографічні особливості тексту та загальноісторичну ситуацію, відносить декрет до першої половини II ст. до н.е., див.: Виноградов Ю.Г. Политическая история Ольвийского полиса VII-I вв. до н.э.... С. 184-186.

43 IOSPE, № 34, строки 6-15.
} 
усіх почесних громадян Ольвії, було вшановано двома скульптурами: почесним бюстом і кінною статуєю. Крім того, вперше в історії Ольвійської громади, його було вшановано щорічною посмертною нагородою вінком і довічним проголошенням глашатаєм під час кінних змагань на честь Ахілла 44 . Встановлення кінної статуї та проголошення під час змагань традиційно робилися на честь тих громадян, які організовували ці змагання або особисто брали у них участь 45 .

Подібні декрети, присвячені організаторам релігійних свят зі змаганнями -

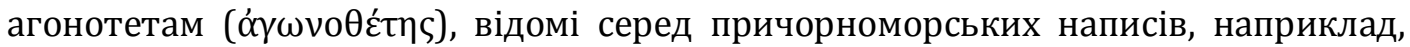
Тіри ${ }^{46}$, Істрії ${ }^{47}$. Це дозволяє припустити виконання Нікератом в Ольвії літургії агонотесії ( $\alpha \gamma \omega v o \theta \varepsilon \sigma i ́ \alpha$, тобто організації змагань). Посмертне проголошення, увінчання, встановлення статуй і стели з почесним декретом свідчать про появу в Ольвії тенденції до героїзації громадян, що особливо відзначилися своїми благодіяннями. Згідно з текстом ольвійського декрету, сам процес похорону Нікерата мав проходити в особливих умовах, відповідно до величі полеглого героя: лавки та майстерні були закриті, громадяни у траурному одязі йшли під час виносу тіла у впорядкованій процесії. Декрет на честь Нікерата відображає прагнення представника Ольвійської аристократії до філантропії та полісного патріотизму. В якості захисника міста, евергета, що раціонально витрачав свої кошти на благодійність, згідно з текстом декрету, він закликає всіх йти по шляху благочестя (

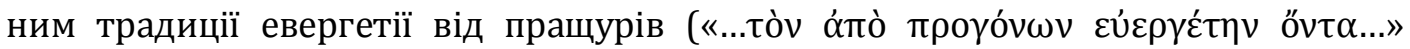
«...той, що був від предків благодійником...») ${ }^{48}$.

Слід виокремити, що у всіх декретах IV-II ст. до н.е. підкреслюється благородне походження місцевих благодійників Ольвії та віддзеркалюються їх благодіяння, проте Рада і Народ, від імені яких були видані ці декрети, не наділяють своїх благодійників окремим статусом, який вирізняв би їх серед інших співгромадян. Термін «евергет», що часто вживається у почесних декретах елліністичного часу, не був титулом і не зіставлявся з обов'язком заможних громадян, які, як підкреслюють тексти, добровільно погоджувалися на численні витрати особистих коштів, захист вітчизни й інших громадян.

Причиною благодійницької діяльності еліти Ольвії, що неодноразово відзначається, була філотімія (благочестя), часто поєднана з полісним патріотизмом, а

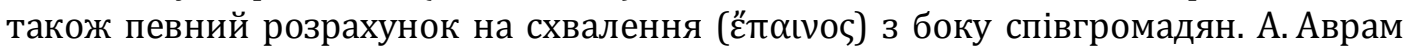
звертає увагу на те, що існування міст Причорноморського регіону й активна діяльність їх евергетів у період еллінізму проходила в умовах домінування держави Мітрідата VI Євпатора та зовнішньої загрози з боку варварів (фракійців, ге-

\footnotetext{
44 Детальне трактування тексту напису див.: Латышев В.В. Исследования об истории и государственном строе Ольвии... С. 141; порівн.: Виноградов Ю.Г. Политическая история Ольвийского полиса VII-I вв. до н. э.... С. 187-188.

45 Русяева А.С. Вопросы развития культа Ахилла в Северном Причерноморье // Скифский мир. Киев, 1975. С. 183-185.

46 У декреті кінця IV - початку III ст. до н.е. з Тіри згадується про обов'язки агонотета стежити за оголошеннями про нагороди під час свята. Див.: Карышковский П.О. Матриалы к собранию древних надписей Сарматии и Тавриды // Вестник древней истории. 1959. № 4. С. 112.

47 У почесному декреті II-I ст. до н.е. з Істрії прославляється багатий громадянин Арістагор, син Апатурія, який у числі інших літургій займався організацією свят. Див.: Блаватская Т.В. Западнопонтийские города в VII-I вв. до н.э. Москва: Изд-во АН СССР, 1952. С. 245-248.

48 IOSPE, № 34, строки 27-29.
} 
тів, кельтів, скіфів, сарматів) ${ }^{49}$. Тому, вочевидь, головною причиною «полісного патріотизму» з боку евергетів було бажання зберегти незалежність поліса, власне життя та майно. Схвалення, на яке розраховували благодійники, виявлялося у славі «доброго громадянина» та в її матеріальних виразах (вінках, статуях, портретах), крім того, вона, у певній мірі, була подібна інституту соціального страхування заможних громадян у межах громадянського колективу.

Таким чином, благодійництво в Ольвійському полісі було формою прояву взаємовідносин між елітою та громадянським колективом у цілому. На ранніх етапах існування поліса діяльність благодійників була зосереджена, головним чином, у межах сакральних союзів. Це сприяло певній сакралізації влади аристократії поліса.

Тривалий період єдиною формою прославлення благодійників були проксенії, які надавалися іноземцям за їх фінансову допомогу полісу. Крім привілеї проксенії, ксени отримували права ольвійських громадян (політія), деякі з них мали право займати почесні місця у міському театрі (проедрія) та привілейованого доступу до суду, Ради і Народних зборів.

До фінансових привілеїв належало звільнення від податків (ателія) або зрівняння у виконанні повинностей з громадянами (ісотелія). Іноземні благодійники мали можливість вільного входу та виходу з гавані, з гарантією особистої та майнової недоторканності, звільнення від митних зборів. 3 IV ст. до н.е. поширюється практика почесних декретів на честь громадян Ольвії. Місцеві благодійники нечасто отримували фінансові привілеї. Публічні вихваляння, однак, часто супроводжувалися конкретними дарами - золотими вінками, грошовими винагородами. Евергетам поліса, за пропозицією Ради та Народних зборів, встановлювалися портретні статуї та рельєфи. Особистості, яких було вшановано у декретах, ставали членами певної групи благодійників (евергетів), але в період демократизації Ольвійського поліса титул «евергета» громадянам не надавався. Це було викликано необхідністю забезпечення внутрішньої політичної стабільності, в іншому випадку даний титул міг надати політичним супротивникам захист демосу. 3 III ст. до н.е., у період економічної та фінансової кризи в Ольвї, в офіційних декретах окремі благодійники - громадяни Ольвії, починають відкрито іменуватися евергетами.

Розглянуті почесні написи відображають утилітарні за своєю суттю політичні та філантропічні аспекти діяльності місцевої еліти Ольвї, що мали перші прояви в елліністичну епоху. Діяльність благодійників покриває конкретні потреби громадянського суспільства у сформованих політико-економічних умовах. У той же час благодійництво демонструє досить обмежені фінансові можливості ольвійських багатіїв (немає відомостей про трієрархію, хорегію й інші літургії, пов'язані з великими фінансовими вкладеннями). Надані привілеї стандартизовані, а їх видове різноманіття обмежено. Проявом вдячності громадянського колективу було увічнення імені благодійника у почесному декреті, що іноді супроводжувалося привілеями адміністративного та фінансового характеру.

\footnotetext{
${ }^{49}$ Avram A. La défense des cités en mer Noire à la basse époque hellénistique // Citoyenneté et participation à la basse époque hellénistique: actes de la table ronde des 22 et 23 mai 2004, Paris / Ed. P. Fröhlich, Ch. Müller. Genève, 2005. Р. 164. Порівн.: Виноградов Ю.Г. Митридат Евпатор и Ольвия // Древнее Причерноморье. Одесса, 1998. С. 42-45.
} 


\section{REFERENCES}

Angel, S. (1999/2000). Euergetai in the Greek Cities in the Black Sea during the Hellenistic Age. MarNero, 4, 89-115.

Avram, A. (2005). La défense des cités en mer Noire à la basse époque hellénistique. In Fröhlich, P. \& Müller, Ch (Eds.). Citoyenneté et participation à la basse époque hellénistique: actes de la table ronde des 22 et 23 mai 2004, Paris. Genève, 163-184 [in French].

Beletskii, A.A. (1955). Grecheskaia nadpis na baze statui iz Olvii [Greek inscription on the basis of a statue from Olbia]. Vestnik drevnei istorii, 2, 180-91 [in Russian].

Blavatskaia, T.V. (1952). Zapadnopontiiskie goroda $v$ 7-1 vv. do n.e. [Western Pontic cities in the $7^{\text {th }}-1^{\text {st }}$ centuries BC]. Moskva: Izd-vo AN SSSR [in Russian].

Brashinskii, I.B. (1963). Drevneishaia Olviiskaia prokseniia [The oldest Olbia proxenia]. Sovetskaia arkheologiia, 3, 191-196 [in Russian].

Cojocaru, V. (2016). Instituţia proxeniei în spaţiul pontic. Cluj-Napoca: Editura MEGA [in Romanian].

Ehrhardt, N. (1983). Milet und seine Kolonien. Frankfurt am Main, Bern, New York: Lang [in German].

Goldhill, S.D. (1987). The Great Dionysia and Civic Ideology. Journal of Hellenic Studies, 107, 58-76.

Gygax, M.D. (2016). Benefaction and rewards in the ancient Greek City: the origins of euergetism. Cambridge, New York: Cambridge University Press.

Herman, G. (2002). Ritualized Friendship and the Greek City. Cambridge: Cambridge University Press.

Ivanchik, A.I. (2011). Stefan, syn Aleksandra iz Smirny: Olviia i eye everget vtoroi poloviny 2 v. do n.e. [Stephanos, son of Alexandros from Smyrna: Olbia and its benefactor in the second half of the $2^{\text {nd }}$ century BC]. Numizmatika i epigrafika, 18, 15-29 [in Russian].

Karyshkovskii, P.O. (1959). Materialy k sobraniiu drevnikh nadpisei Sarmatii i Tavridy [Materials for the collection of ancient inscriptions of Sarmatia and Taurid]. Vestnik drevnei istorii, 4, 111-113 [in Russian].

Karyshkovskii, P.O. (1984). Olviiskie molpy [Olbian molpos]. In Dzis-Raiko, G.A. (Ed.). Severnoe Prichernomorie: materialy po arkheologii. Kiev: Nukova dumka, 42-51 [in Russian].

Knipovich, T.N. \& Levi, E.I. (Eds.). (1968). Nadpisi Olvii (1917-1965) [Inscriptions of Olbia]. Leningrad: Nauka [in Russian].

Kozhokaru, V. \& Litsu, A. (2009). Proksenicheskie dekrety kak instrument vzaimootnosheniy s chuzhezemtsami v pontiiskikh grecheskikh obshchestvakh i na ostrove Kos: predvaritelnyie itogi sravnitelnogo issledovaniia [The Proxenia as a tool for relationships with foreigners in Pontic Greek societies and in Kos: preliminary results of a comparative study]. In Bocharova, S.G., Kozhokaru, V. (Eds.). Severnoe i Zapadnoe Prichernomorie v antichnuiu epokhu i srednevekovie. Simferopol: Tavriia, 186-216 [in Russian].

Kryzhitskii, S.D., Rusiaeva, A.S., Krapivina, V.V. \& et al. (Eds.) (1999). Olviia. Antichnoe gosudarstvo $v$ Severnom Prichernomorie [Olbia. Ancient State in the Northern Black Sea Region]. Kiev: Izdatelstvo IA NANU [in Russian].

Latyschev, V.V. (Ed.) (1916). Inscriptiones antiquae orae septentrionalis Ponti Euxini Graecae et Latinae. Vol. 1. Ed. 2. Petropolis.

Latyshev, V.V. (1887). Issledovaniia ob istorii i gosudarstvennom stroe Olvii [Studies on the history and polity of Olbia]. Sankt-Peterburg [in Russian].

Mihailov, G. (Ed.) (1970). Inscriptiones graecae in Bulgaria repertae. Vol. 1. Ed. 2. Serdicae: Academiae Litterarum Bulgaricae.

Nikitiuk, E.V. (2001). Institut proksenii v mezhpolisnykh otnosheniiakh v klassicheskoi Gretsii [The Proxenia in Interpolisal Relations in Classical Greece]. Antichnoe obshchestvo: vlast i obshchestvo v antichnosti, (Vol. 4, pp. 54-58). Sankt-Peterburg [in Russian].

Nikolaev, N.I. (2014). Prosopografiia Olvii Pontiiskoi 5 v. do n.e. -1 v. n.e. [Prosopography of Pontic Olbia in the $5^{\text {th }}$ century BC $-1^{\text {st }}$ century AD]. Kiev: Izdatelstvo O. Filiuk [in Russian].

Pippidi, D.M. (1975). Scythica Minora: recherches les colonies grecques du littoral roumain de la mer Noire. București; Amsterdam: Acad. RSR, Hakkert [in Romanian].

Pippidi, D.M. (Ed.) (1983). Inscripţiile din Scythia Minor grecești şi latine. Vol. I. Histria și împrejurimile. București: Editura Acad. RSR [in Romanian].

Rusiaeva, A.S. (2002). Abab, syn Kallisfena - politicheskii deiatel Olvii Pontiiskoi [Abab, son of Kallisphenos is the politician of Olbia Pontic]. Antichnyi mir i arkheologiia, (Vol. 11, pp. 182-186). Saratov [in Russian].

Rusiaeva, A.S. (1986). Milet-Didimy-Borisfen-Olviia. Problemy kolonizatsii Nizhnego Pobuzhia [MiletusDidyma-Borisfen-Olbia. Problems of colonization of the Lower Bug]. Vestnik drevnei istorii, 2, 25-64 [in Russian]. 
Rusiaeva, A.S. (1993). Protogen Olviiskii [Protogenos from Olbia]. Arkheolohiia, 2, 14-24 [in Russian].

Rusiaeva, A.S. (1992). Religiia i kulty antichnoi Olvii [Religion and cults of ancient Olbia]. Kiev: Naukova dumka [in Russian].

Treister, M.Yu. (1999). Materialy k korpusu postamentov bronzovykh statui Severnogo Prichernomoria [Materials for the collection of the pedestals of bronze statues of the Northern Black Sea Region]. Khersonesskii sbornik, 10, 121-159 [in Russian].

Vinogradov, Yu.G. (1998). Mitridat Evpator i Olviia [Mithridates Eupator and Olbia]. In Stanko, V.N. (Ed.). Drevnee Prichernomorie. Odessa: Odesskii gosudarstvennyi universitet imeni I.I. Mechnikova, pp. $42-45$ [in Russian].

Vinogradov, Yu.G. (1989). Politicheskaia istoriia Olviiskogo polisa 7-1 vv. do n.e.: Istoriko-epigraficheskoe issledovanie [Political history of the Olbia polis the $7^{\text {th }}-1^{\text {st }}$ centuries BC: Historical and epigraphic research]. Moskva: Nauka [in Russian].

Vinogradov, Yu.G. \& Karyshkovskii, P.o. (1982). Kallinik, syn Evksena. Problemy politicheskoi i sotsialno-ekonomicheskoi istorii Olvii vtoroi poloviny 4 v. do n.e. [Kallinikos, son of Euxenos. Problems of the political, social and economic history of Olbia in the second half of the $4^{\text {th }}$ century BC]. Vestnik drevnei istorii, 4, 26-46 [in Russian].

Yailenko, V.P. (1989). Olviiskii dekret v chest synovei khersonesita Apolloniia [Olbian decree in honor of the sons of Apollonios from Chersonesos]. In Shishkin, V.A. (Ed.). Vspomagatelnye istoricheskie distsipliny. Leningrad: Nauka, 252-268 [in Russian].

Yailenko, V.P. (2015). Slovo i delo: o publikatsii Olviiskogo dekreta v chest smirneitsa Stefana [Word and deed: about the publication of the Olbian decree in honor of Stephanos from Smyrna]. Antichnyi mir i arkheologiia, (Vol. 17, pp. 195-208). Saratov: Izd-vo Saratovskogo universiteta [in Russian].

Zhebelev, S.A. (1953). Severnoe Prichernomorie: Issledovaniia i statyi po istorii antichnoi epokhi. [Northern Black Sea Region: Studies and Articles on the History of the Ancient Period]. Moskva, Leningrad: Izdatelstvo AN SSSR [in Russian].

\section{Oksana Ruchynska}

(V.N. Karazin Kharkiv National University, Kharkiv, Ukraine)

e-mail: o.a.ruchynska@karazin.ua

ORCID: https://orcid.org/0000-0002-6776-1598

\section{Characteristics of Charity in Olbian Polis (VI-I BC)}

The article deals with analysis of charity in Olbian polis which was inherent in both citizens and foreigners from the moment of the foundation of the polis to the end of the Hellenistic period. It is argued, that the Olbian elite had very often engaged in practices owing much to euergetism.

In the early stages of the polis existence, the activity of benefactors was concentrated mainly on sacred unions. This fact contributed to the sacralization of the power of aristocracy in the city. For a long time the single form of benefactors' glorification was proxenia, granted to foreigners for their financial assistance to the polis. According to proxenia and honorific decrees such a kind of emergency liturgy as the epidosis (voluntary donations) was popular in Olbian polis among both rich foreigners and Olbiopolitans. It should be emphasized that we do not observe official gratitude texts from civil communities towards their benefactors at the early stage of the history of the polis. The position of the everget gave foreigners a special status in the Olbian polis.

Since the 4th century BC the decrees in honor of the citizens of Olbia began to spread. It should be noted that all the decrees of the 4th-2nd centuries BC represented the benefactions of the local evergets in Olbia and emphasized their noble origin, but the Council and the people, on whose behalf these decrees were issued, did not confer their benefactors on a separate status to prevent their distinction from other fellow citizens. The term «everget», often used in honorific decrees of Hellenistic time, was not a title and was not compared with the duty of wealthy citizens who voluntarily agreed to numerous personal funds expenditure as well as 
protection of fatherland and fellow citizens. Philotimia (piety) was repeatedly noted in the texts as a reason for the charity work of the Olbian elite. It was often associated with patriotism and certain expectations to get «praise» (epainesai) from fellow citizens. «Praise» manifested itself in the glory of a "good citizen» and in its material donations (wreaths, statues, portraits, etc.). Moreover, it served as a kind of institution of social insurance for wealthy citizens within the civil community.

The activities of the native benefactors covered specific needs of the civil community in the prevailing political and economic conditions. At the same time that activity reflected rather limited financial possibilities of the Olbian rich (there is no information about the trierarkhia, horegia and other liturgies associated with large financial investments). Granted privileges were standardized and their diversity was limited. The gratitude of the civil community was manifested in perpetuating of the benefactor's name, which sometimes was accompanied by administrative and financial privileges.

Keywords: charity, euergetism, Olbian polis, elite, civil society 